\title{
Clinical Reasoning: A 31-Year-Old Man With Sequential Vision Loss
}

Blake Fortes, MD, John J. Chen, MD, PhD, and M. Tariq Bhatti, MD

Neurology ${ }^{\circledR}$ 2022;98:163-169. doi:10.1212/WNL.0000000000013084
Correspondence

Dr. Bhatti

bhatti.muhammad@

mayo.edu

\begin{abstract}
A 31-year-old healthy White man experienced painless sequential vision loss. Brain imaging and laboratory investigations for infectious, inflammatory, and nutritional conditions, in addition to targeted genetic testing for Leber hereditary optic neuropathy (LHON), were all normal or negative. Despite systemic corticosteroid therapy and plasma exchange, vision continued to worsen. Eventually, mitochondrial whole-genome sequencing was performed, which demonstrated a mutation at the $13513 \mathrm{G}>\mathrm{A}$ position confirming the diagnosis of $\mathrm{LHON}$. The three primary mutations ( $11778 G>A, 14484 T>C$, and $3460 G>A$ ) account for $90 \%$ of LHON cases; therefore, it is important to consider whole-genome mitochondrial sequencing in cases with a high index of clinical suspicion and negative primary mutation screening testing.
\end{abstract}

From the Department of Ophthalmology (B.F., J.J.C., M.T.B.) and Department of Neurology (.J.C., M.T.B.), Mayo Clinic College of Medicine; Rochester, MN.

Go to Neurology.org/N for full disclosures. Funding information and disclosures deemed relevant by the authors, if any, are provided at the end of the article. 


\section{Section 1}

A 31-year-old healthy White man was referred for painless sectoral cloudy vision in the left eye that occurred over several days after experiencing a similar episode 4 months before in the right eye. He had initially presented to a local ophthalmologist a month after vision loss in the right eye. At that time, he was noted to have a visual acuity of 20/40 in the right eye and 20/20 in the left eye with a right relative afferent pupillary defect (RAPD) and was able to identify only $1 / 13$ Ishihara pseudoisochromatic color plates in the right eye $(13 / 13$ in the left eye). The appearance of his optic discs and retinas was reported to be normal in both eyes. Automated visual field (AVF) testing demonstrated a superior field defect in the right eye and normal findings in the left eye. There was no family history of unexplained visual loss, and he denied recreational drug use but endorsed consuming 2 glasses of alcohol daily and smoking 1 pack of cigarettes per day. He ate a healthy varied diet.

\section{Questions for Consideration:}

1. What is the differential diagnosis for an RAPD and decreased color vision?

2. What further clinical testing would you order?

GO TO SECTION 2 


\section{Section 2}

An RAPD, detected by performing the swinging flashlight test, is typically indicative of an optic neuropathy. ${ }^{1}$ Dyschromatopsia or deficiency in color vision can be either congenital or acquired. The Ishihara pseudoisochromatic color plates are often used clinically to screen for acquired dyschromatopsia, but the original purpose of the test was to identify congenital red-green color blindness. ${ }^{2}$ The combination of unilateral visual loss, dyschromatopsia, and an RAPD is strongly suggestive of an optic neuropathy. The differential diagnosis of optic neuropathy is broad and can be considered under the general categories of toxic, metabolic, nutritional, ischemic, infectious, inflammatory, compressive/neoplastic, traumatic, and hereditary conditions (eTable 1). ${ }^{3}$ Because he was healthy, was not taking any medications, and had no recent history of trauma, it was unlikely that he has a toxic, metabolic, nutritional, or traumatic optic neuropathy. Ischemic optic neuropathy is also unlikely given his young age and the lack of risk factors such as diabetes mellitus, hypertension, hyperlipidemia, or obstructive sleep apnea. If this were ischemic optic neuropathy, it would have to be posterior ischemic optic neuropathy due to the lack of optic disc edema, which is rare outside surgery (i.e., prone position spine surgery), severe blood loss, or a vasculitic process. The absence of pain with eye movement decreases the likelihood of optic neuritis. Neuroimaging is needed to exclude an intrinsic optic nerve or intracranial compressive lesion.

MRI of the brain and orbits with contrast was unremarkable with no optic nerve enhancement or periventricular white matter lesions. An extensive laboratory investigation for inflammatory, infectious, autoimmune conditions, and nutritional deficiencies was all normal or negative: erythrocyte sedimentation rate $4 \mathrm{~mm} / \mathrm{hr}$, C-reactive protein $<5.0 \mathrm{~m} / \mathrm{dL}$ $(0.0-10.0 \mathrm{~m} / \mathrm{dL})$, angiotensin-converting enzyme $18 \mathrm{U} / \mathrm{L}$ (9-67 U/L), C3 complement $123 \mathrm{mg} / \mathrm{dL}$ (88-165 mg/dL), C4 complement $27.7 \mathrm{mg} / \mathrm{dL}(14.0-44.0 \mathrm{mg} / \mathrm{dL})$, vitamin B12 $861 \mathrm{pg} / \mathrm{mL}(239-931 \mathrm{pg} / \mathrm{mL})$, folate $15.9 \mathrm{ng} / \mathrm{mL}$ (>2.8 $\mathrm{ng} / \mathrm{mL}$ ), PCR for severe acute respiratory syndrome coronavirus 2, human immunodeficiency virus, herpes simplex virus types 1 and 2, JC virus, and serology for hepatitis $\mathrm{A}$, hepatitis $\mathrm{B}$, and hepatitis $\mathrm{C}$ virus, West Nile virus, Treponema pallidum, Borrelia burgdorferi, Tropheryma whipplei, rheumatoid factor, antinuclear antigen, anticyclic citrullinated peptide, double-stranded DNA, anti-Smith, proteinase-3, myeloperoxidase, and anticardiolipin. No monoclonal proteins were detected on serum protein electrophoresis. He was given the presumptive diagnosis of atypical retrobulbar optic neuritis by the local ophthalmologist and treated with 3 consecutive days (1 gram per day) of IV methylprednisolone followed by a 2week oral prednisone taper.

Four months later, vision declined to $20 / 60$ in the right eye and $20 / 40$ in the left eye. Color vision was $1 / 13$ in each eye. There was mild temporal optic disc pallor of the right eye and subtle hyperemia of the left optic disc. A repeat MRI of the brain and orbits with contrast was negative as was a cervical spine MRI.

\section{Question for Consideration:}

1. What further testing would you order?

\section{GO TO SECTION 3}




\section{Section 3}

Because of the uncertainty regarding the etiology of visual loss, autoimmune and genetic causes were considered. Aquaporin 4 and myelin oligodendrocyte glycoprotein antibodies were negative. Lumbar puncture demonstrated opening pressure of $17 \mathrm{~cm} \mathrm{H}_{2} \mathrm{O}$, leukocytes $2 / \mu \mathrm{L}$, erythrocytes 0 , glucose $95 \mathrm{mg} / \mathrm{dL}$, protein $73 \mathrm{mg} / \mathrm{dL}$, and absence of oligoclonal bands. Genetic testing for the 3 primary mitochondrial DNA (mtDNA) mutations (11778G>A, $14484 T>C$, and $3460 G>A$ ) for Leber hereditary optic neuropathy (LHON) was negative. He was again treated with 3 consecutive days of IV methylprednisolone in addition to concomitant plasma exchange for 7 days for presumed atypical optic neuritis without improvement in vision.

Approximately 5 months later, vision was $20 / 80$ in both eyes. There was no RAPD. Color plates were $1 / 13$ in each eye.

Figure 1 Color Fundus Photographs Showing Bilateral Temporal Optic Disc Pallor
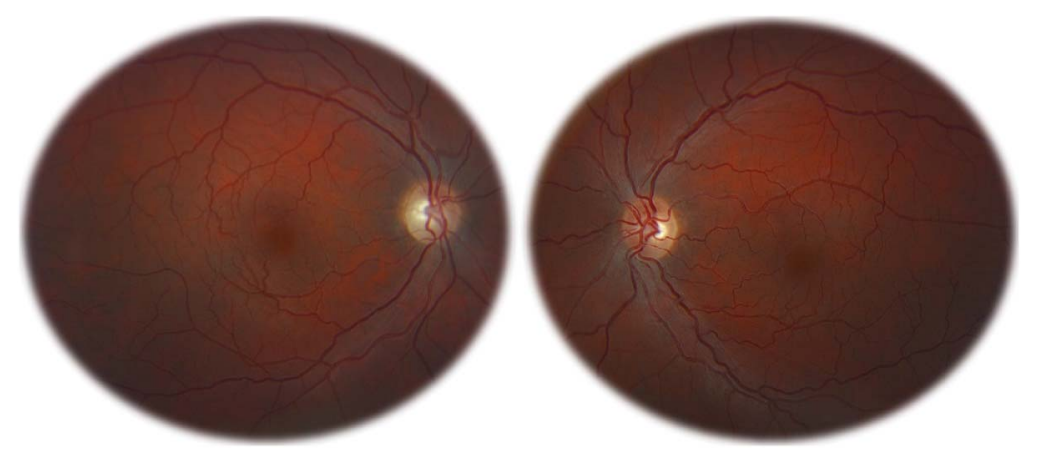

Figure 2 Optical Coherence Tomography Peripapillary Retinal Nerve Fiber Layer Analysis Demonstrates Temporal and Inferior Thinning of the Right Eye (Average Thickness $69 \mu \mathrm{m}$ ) and Temporal Thinning of the Left Eye (Average Thickness $84 \mu \mathrm{m}$ )

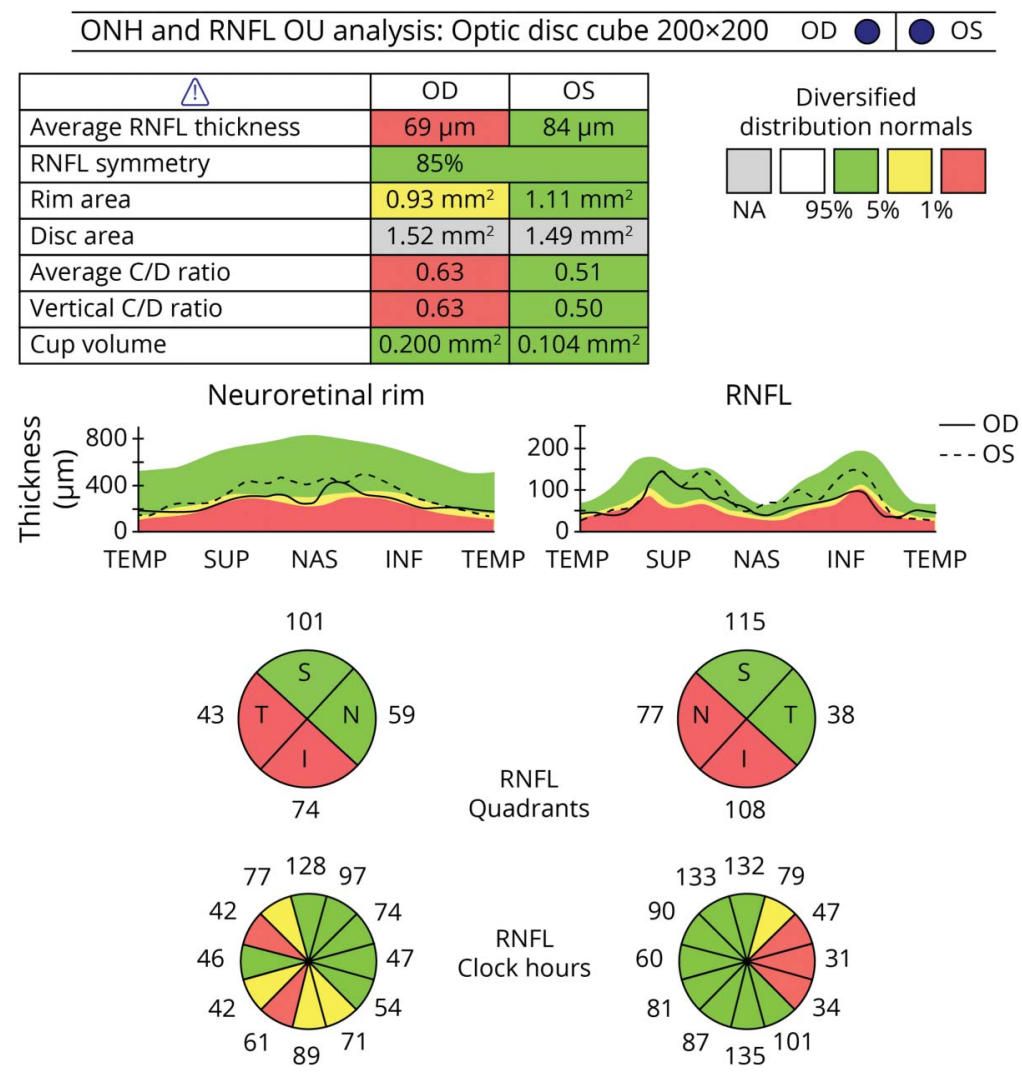


Fundus examination demonstrated mild bilateral temporal optic disc pallor (Figure 1). AVF testing showed bilateral central scotomas (eFigure 1, links.lww.com/WNL/B664). Optical coherence tomography (OCT) demonstrated temporal and inferior peripapillary retinal nerve fiber ( $\mathrm{pRNFL}$ ) thinning in the right eye, temporal pRNFL thinning in the left eye (Figure 2), and bilateral ganglion cell layer-inner plexiform layer (GCIPL) thinning (eFigure 2, links.lww.com/WNL/B664).

Questions for Consideration:

1. What is the clinical significance of the OCT findings?

2. What is the next step in the management?

\section{GO TO SECTION 4}




\section{Section 4}

The OCT findings are consistent with bilateral optic neuropathies but are not specific in terms of determining the underlying etiology. However, the patterns of temporal pRNFL thinning and GCLIPL thinning represent preferential loss of the papillomacular fibers, which are small caliber unmyelinated axons with a high concentration of mitochondria, that carry the accumulated retinal ganglion cell signal for central vision. ${ }^{4,5}$ The sequential painless visual loss due to optic nerve dysfunction in a young male with this optic nerve appearance, AVF findings, and OCT pattern is most compatible with LHON despite the negative targeted mitochondrial testing. Mitochondrial whole-genome sequencing demonstrated an mtDNA mutation at the $13513 G>A$ position with a heteroplasmy level of $7 \%$, confirming LHON. An electrocardiogram did not detect a cardiac arrhythmia. ${ }^{6}$

\section{Discussion}

LHON is a maternally inherited, mitochondrial disease that typically affects males with an $80 \%-90 \%$ predominance, and onset usually occurs between ages 15 and 35 years. ${ }^{6}$ The 3 primary mtDNA mutations $(11778 G>A, 14484 T>C$, and $3460 G>A$ ) account for approximately $90 \%$ of LHON cases. ${ }^{6}$ The remaining $10 \%$ of cases are the result of point mutations at other mtDNA positions and within the nuclear DNA. ${ }^{7}$

The classic presentation of LHON is acute to subacute, painless, central visual loss that may progress over weeks to months. In up to $50 \%$ of cases, the visual loss is bilateral and simultaneous, and in the other half, it is sequential with second eye involvement usually within 3 months. ${ }^{6}$ Most patients develop dense central or cecocentral scotomas with visual acuity of 20/200 or worse. ${ }^{6}$ Depending on the symmetry of involvement, patients may have an RAPD. On funduscopic examination, the optic disc may demonstrate peripapillary telangiectasias and elevation of the pRNFL representing pseudo-optic disc edema. However, in some patients, the optic disc will appear normal during the acute phase. In the chronic phase (>3-6 months), optic disc pallor will develop, occasionally associated with optic disc cupping. OCT may demonstrate increased pRNFL thickness over the first 3-6 months, which subsequently becomes progressively thinner, especially in the temporal quadrant because of preferential involvement of the papillomacular bundle as mentioned above. $^{4}$

In most instances, vision loss is permanent, but a minority of patients may experience some degree of visual recovery either in central visual acuity or development of openings within the visual field defect 6-12 months after the onset of visual loss. Positive prognostic factors for visual improvement include the $14484 T>C$ mutation and age at onset before age 20 years.
Environmental factors, particularly alcohol and tobacco smoking, have been associated with increased penetrance of LHON; therefore, most patients are advised to eliminate alcohol and tobacco consumption. ${ }^{6}$

The $13513 G>A$ variant is the most frequently reported mutation in the ND5 gene. The mutation is commonly associated with Leigh syndrome or mitochondrial encephalomyelopathy, lactic acidosis, and stroke-like episodes (MELAS) but only rarely with LHON. ${ }^{8-10}$ Genetic mutation load (i.e., heteroplasmy) is an important factor in the risk of vision loss in LHON related to a phenotypic expression threshold, but not necessarily to illness severity or multiorgan involvement. ${ }^{11}$ The ND5 protein, a hydrophobic polypeptide, is one of 45 subunits ( 38 of which are nuclear DNA encoded and $7 \mathrm{mtDNA}$ encoded) of complex I within the electron transport chain. The ND5 gene is the largest of the mtDNAencoded complex I genes. ${ }^{12}$ ND5 synthesis is the ratelimiting step for the activity of complex I and therefore of oxidative phosphorylation, which explains why even low mutant loads can cause clinical manifestations. ${ }^{12}$ Significant mitochondrial impairment leads to the increased formation of reactive oxygen species and reduced adenosine triphosphate production culminating in cell apoptosis. ${ }^{11}$ This case illustrates the importance of whole-genome mitochondrial sequencing when initial screening for the 3 common mtDNA pathogenic variants is negative.

\section{Follow-up}

It was recommended that he start idebenone, a short-chain benzoquinone synthetic analog of ubiquinone (coenzyme Q10), which is approved by the European Medicines Agency in the treatment of LHON and has been shown to have a modest benefit in improving vision in some patients. ${ }^{13,14} \mathrm{He}$ was also advised to eliminate alcohol and tobacco consumption.

\section{Study Funding}

No targeted funding reported.

\section{Disclosure}

The authors report no disclosures relevant to the manuscript. Go to Neurology.org/ $\mathrm{N}$ for full disclosures.

\section{Appendix Authors}

\begin{tabular}{lll}
\hline Name & Location & Contribution \\
\hline $\begin{array}{l}\text { Blake H. } \\
\text { Fortes, MD }\end{array}$ & $\begin{array}{l}\text { Mayo Clinic, } \\
\text { Rochester, MN }\end{array}$ & $\begin{array}{l}\text { Major role in drafting the manuscript and } \\
\text { figures }\end{array}$ \\
\hline $\begin{array}{l}\text { John J. Chen, } \\
\text { MD, PhD }\end{array}$ & $\begin{array}{l}\text { Mayo Clinic, } \\
\text { Rochester, MN }\end{array}$ & $\begin{array}{l}\text { Revised the manuscript for intellectual } \\
\text { content }\end{array}$ \\
$\begin{array}{l}\text { M. Tariq } \\
\text { Bhatti, MD }\end{array}$ & $\begin{array}{l}\text { Mayo Clinic, } \\
\text { Rochester, MN }\end{array}$ & $\begin{array}{l}\text { Design and conceptualized the study and } \\
\text { revised the manuscript for intellectual } \\
\text { content }\end{array}$ \\
\hline
\end{tabular}




\section{References}

1. Digre KB. Principles and techniques of examination of the pupils, accommodation, and lacrimation. In: Miller NR, Newman NJ, Biousse VB, Kerrison JB, eds. Walsh and Hoyt's Clinical Neuro-Ophthalmology, 6th ed. Lippincott Williams and Wilkins; 2005.

2. Ishihara S. Tests for Color-Blindness: Hongo Harukicho; 1917.

3. Abou Zeid N, Bhatti MT. Acute inflammatory demyelinating optic neuritis: evidencebased visual and neurological considerations. Neurologist. 2008;14(4):207-223.

4. Barboni P, Carbonelli M, Savini G, et al. Natural history of Leber's hereditary optic neuropathy: longitudinal analysis of the retinal nerve fiber layer by optical coherence tomography. Ophthalmology. 2010;117(3):623-627.

5. Rosdahl JA, Asrani S. Glaucoma masqueraders: diagnosis by spectral domain optical coherence tomography. Saudi J Ophthalmol. 2012;26(4):433-440.

6. Fraser JA, Biousse V, Newman NJ. The neuro-ophthalmology of mitochondrial disease. Surv Ophthalmol. 2010;55(4):299-334.

7. Mansukhani SA, Mehta DG, Renaud DL, Whealy MA, Chen JJ, Bhatti MT. Nuclear DNA mutation causing a phenotypic Leber hereditary optic neuropathy plus. Ophthalmology. 2021;128(4):628-631.
8. Chen BS, Biousse V, Newman NJ. Mitochondrial DNA 13513G >A mutation presenting with Leber's hereditary optic neuropathy. Clin Exp Ophthalmol. 2019;47(9):1202-1204.

9. Chol M, Lebon S, Bénit P, et al. The mitochondrial DNA G13513A MELAS mutation in the NADH dehydrogenase 5 gene is a frequent cause of Leigh-like syndrome with isolated complex I deficiency. J Med Genet. 2003;40(3):188-191.

10. Krylova TD, Sheremet NL, Tabakov VY, et al. Three rare pathogenic mtDNA substitutions in LHON patients with low heteroplasmy. Mitochondrion. 2020;50:139-144.

11. Sun CB, Bai HX, Xu DN, Xiao Q Liu Z. Mitochondrial 13513G>A mutation with low mutant load presenting as isolated Leber's hereditary optic neuropathy assessed by next generation sequencing. Front Neurol. 2021;12:601307.

12. Blok MJ, Spruijt L, de Coo IF, Schoonderwoerd K, Hendrickx A, Smeets HJ. Mutations in the ND5 subunit of complex I of the mitochondrial DNA are a frequent cause of oxidative phosphorylation disease. J Med Genet. 2007;44(4):e74.

13. Lyseng-Williamson KA. Idebenone: a review in Leber's hereditary optic neuropathy. Drugs. 2016;76(7):805-813.

14. Klopstock T, Metz G, Yu-Wai-Man P, et al. Persistence of the treatment effect of idebenone in Leber's hereditary optic neuropathy. Brain. 2013;136(pt 2):e230.

\section{Did You Know...}

... you can browse by subspecialty topics on Neurology.org?

Go to: Neurology.org and click on "Collections" in the top navigation bar, then choose "Topics A-Z" from the drop down menu.

\section{Online Learning for Everyone}

No matter your career stage, interest, or learning style, the AAN has a wide variety of convenient online CME, self-assessment, and other learning activities to suit your needs. From bite-sized learning opportunities to self-assessment programs, help preparing you for the boards or continuing certification, or on-demand access to popular AAN conferences, the AAN has you covered. Visit AAN.com/Learn today.

\section{Share Your Artistic Expressions in Neurology 'Visions'}

AAN members are urged to submit medically or scientifically related artistic images, such as photographs, photomicrographs,

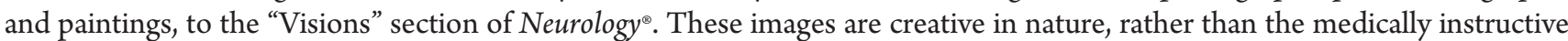
images published in the NeuroImages section. The image or series of up to six images may be black and white or color and must fit into one published journal page. Accompanying description should be 100 words or less; the title should be a maximum of 140 characters including spaces and punctuation.

Please access the Author Center at NPub.org/authors for full submission information. 


\section{Neurology}

\section{Clinical Reasoning: A 31-Year-Old Man With Sequential Vision Loss}

Blake Fortes, John J. Chen and M. Tariq Bhatti

Neurology 2022;98;163-169 Published Online before print November 19, 2021

DOI 10.1212/WNL.0000000000013084

This information is current as of November 19, 2021

\section{Updated Information \&} Services

References

Subspecialty Collections

Permissions \& Licensing

Reprints including high resolution figures, can be found at: http://n.neurology.org/content/98/4/163.full

This article cites 12 articles, 2 of which you can access for free at: http://n.neurology.org/content/98/4/163.full\#ref-list-1

This article, along with others on similar topics, appears in the following collection(s):

All Epilepsy/Seizures

http://n.neurology.org/cgi/collection/all_epilepsy_seizures All Neuro-ophthalmology

http://n.neurology.org/cgi/collection/all_neuroophthalmology

Mitochondrial disorders

http://n.neurology.org/cgi/collection/mitochondrial_disorders

Optic nerve

http://n.neurology.org/cgi/collection/optic_nerve

Status epilepticus

http://n.neurology.org/cgi/collection/status_epilepticus

Visual loss

http://n.neurology.org/cgi/collection/visual_loss

Information about reproducing this article in parts (figures,tables) or in its entirety can be found online at:

http://www.neurology.org/about/about_the_journal\#permissions

Information about ordering reprints can be found online:

http://n.neurology.org/subscribers/advertise

Neurology ${ }^{\circledR}$ is the official journal of the American Academy of Neurology. Published continuously since 1951, it is now a weekly with 48 issues per year. Copyright () 2021 American Academy of Neurology. All rights reserved. Print ISSN: 0028-3878. Online ISSN: 1526-632X.

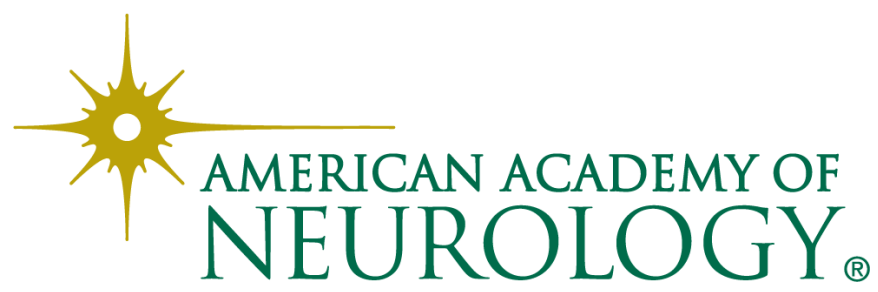

